\title{
Pengembangan Model Hewan Coba Tikus Diabetes Mellitus Tipe 2 dengan Induksi Diet Tinggi Fruktosa Intragastrik
}

\author{
Devyani Diah Wulansari ${ }^{1}$, Devyana Dyah Wulandari ${ }^{2}$ \\ ${ }^{1}$ Laboratorium Farmasi Klinis dan Komunitas, Fakultas Farmasi, Universitas Surabaya \\ ${ }^{2}$ Program Studi D-IV Analis Kesehatan, Fakultas Kesehatan, Universitas Nahdlatul Ulama Surabaya \\ Correspondence: Devyani Diah Wulansari \\ Email: devyanidiahwulansari@staff.ubaya.ac.id
}

\begin{abstract}
ABSTRAK: Pada beberapa tahun terakhir banyak dikembangkan model hewan diabetes mellitus untuk memahami patogenesis, komplikasi, dan pengaruh genetik yang meningkatkan risiko diabetes mellitus tipe 2, baik dengan menggunakan bahan kimia maupun dengan modifikasi secara genetik termasuk tikus knockout transgenik, umum, dan knockout spesifik jaringan. Dalam penelitian ini model hewan diabetes mellitus tipe 2 dikembangkan melalui metode pendekatan konsumsi gula pada manusia dengan mengacu pada karakteristik kondisi diabetes mellitus tipe 2, penyebab atau mekanisme yang mendasari, serta pertimbangan keuntungan dan kerugian bagi para peneliti dalam penelitian diabetes. Penelitian ini menggunakan 32 ekor hewan coba, diadaptasikan selama 14 hari kemudian dibagi dalam 4 kelompok yaitu kelompok kontrol, kelompok perlakuan yang diberi larutan fruktosa 2, 5, dan $9 \mathrm{~g} / \mathrm{kgBB}$ selama 56 hari. Hasil uji komparasi menunjukkan bahwa terdapat perbedaan bermakna antar kelompok $(p<0,05)$ pada variabel dosis fruktosa dan gula darah puasa akhir. Dari penelitian ini dapat disimpulkan bahwa pemberian fruktosa secara intragastrik jangka panjang dapat memicu kenaikan glukosa darah puasa pada tikus.
\end{abstract}

Kata Kunci: Model hewan diabetes mellitus; diet tinggi fruktosa; glukosa darah; diabetes

\begin{abstract}
In recentyears a large number of animal models of type 2 diabetes mellitus (DM) have been developed to understand the pathogenesis, complications, and genetic influences that increase the risk of type 2 DM, either by using chemicals or by genetic modification including transgenic knockout mice, general and tissue-specific knockouts. In this experiment, animal models of type 2 DM were developed through high fructose diet that was similar to actual human consumption with approach to the characteristics of type 2 DM, underlying cause or mechanism, and consideration of the advantages and disadvantages for researchers in diabetes research. This study used 32 animals, adapted for 14 days then divided into 4 groups: control group, treatment group given fructose solution 2, 5, and $9 \mathrm{~g} / \mathrm{kg}$ body weight for 56 days. The comparative test results showed that there were significant differences between groups ( $p<0.05)$ in the fructose dose and fasting blood glucose concentration. From this study it can be concluded that long-term intragastric fructose can induce the increase of fasting blood glucose in mice.
\end{abstract}

Keywords: Diabetes mellitus animal model; high fructose diet; blood glucose; diabetes 


\section{Pendahuluan}

Diabetes mellitus (DM) adalah kondisi yang ditandai dengan kelainan klinik dan genetik yang heterogen, gejala yang ditunjukkan berupa hiperglikemia akibat insufisiensi fungsi insulin. Beberapa penelitian terdahulu menyatakan bahwa pada tahun 2013 terdapat 382 juta orang hidup dengan DM di dunia, dan diperkirakan 175 juta di antaranya belum terdiagnosis, dan terancam berkembang progresif menjadi komplikasi dan tanpa pencegahan [1].

DM merupakan salah satu penyakit yang termasuk dalam kriteria penyakit tidak menular (PTM). Penyakit tidak menular sudah menjadi masalah kesehatan masyarakat, baik secara global, regional, nasional dan lokal. Di Indonesia DM merupakan ancaman serius bagi pembangunan kesehatan karena dapat menimbulkan gangguan multiorgan. Prevalensi DM di Indonesia berdasarkan Riset Kesehatan Dasar tahun 2013 sebesar 1,5\% dan di Provinsi Jawa Timur 2,1\% sehingga prevalensi DM di Jawa Timur tergolong cukup tinggi. Pada Tahun 2030 diperkirakan DM menempati urutan ke-7 penyebab kematian dunia, sedangkan Indonesia diperkirakan sebanyak 21,3 juta jiwa. [1].

Beberapa tahun terakhir banyak dikembangkan model hewan diabetes mellitus untuk mempelajari mekanisme dan/atau penyebab yang mendasari terjadinya DM ataupun untuk menguji senyawa yang diduga memiliki efek sebagai antidiabetik. Beberapa model hewan diabetes mellitus yang dikembangkan meliputi induksi kimia, pembedahan (pankreatektomi), bahkan sampai tingkat manipulasi genetik untuk memicu kondisi DM.

Peningkatan prevalensi penderita DM yang sangat cepat berhubungan dengan adanya perubahan gaya hidup meliputi penurunan aktifitas fisik dan pola makan yang tidak terkontrol. Perkembangan kondisi DM tipe 2 sejalan dengan beberapa gangguan metabolik seperti hipertensi, dislipidemia dan obesitas, yang berhubungan erat dengan konsumsi tinggi gula, terutama jenis gula fruktosa. Fruktosa banyak ditemui sebagai pemanis pada makanan dan minuman seperti softdrinks.

Mekanisme fruktosa (fruktolisis) berbeda dengan glukosa (glikolisis). Dalam hati, fruktosa tidak diregulasi oleh glukokinase/heksokinase dan fosfofruktokinase, selain itu jalur fruktolisis ini tidak dihambat oleh produknya (fruktosa1-fosfat). Fruktosa-1-fosfat bukan merupakan alosterik inhibitor pada jalur fruktolisis, tidak seperti enzim kunci glikolisis. Fruktosa adalah regulator utama penyerapan glukosa dan sintesis glikogen di hati [2].

Pemberian fruktosa $20-25 \%$ selama 12 minggu pada tikus dapat menginduksi perkembangan penanda sindroma metabolik yang progresif (hipertensi dan peningkatan berat badan) yang mengindikasikan terjadinya resistensi insulin. Pemberian selama 12 minggu pada penelitian terdahulu dapat menunjukkan awal terjadinya diabetes mellitus tipe 2 (130-150 mg/dl). Pemberian dalam jangka waktu yang lebih lama dapat memicu diabetes mellitus tipe 2. Model induksi ini didasarkan pada pola konsumsi diet tinggi fruktosa pada manusia dewasa. Tujuan dari penelitian ini adalah untuk mengembangkan model induksi diabetes mellitus tipe 2 dan resistensi insulin menggunakan diet tinggi fruktosa pada tikus wistar jantan, dengan pendekatan pola konsumsi diet tinggi fruktosa pada manusia [3].

\section{Bahan dan metode \\ 2.1. Hewan uji dan diet}

Sampel dalam penelitian ini adalah tikus putih (Rattus novergicus) strain Wistar dengan kriteria inklusi yaitu berjenis kelamin jantan, berusia 4-6 minggu, berat badan 150-200 gram, dalam kondisi sehat, dan tidak menderita DM dengan kadar glukosa darah acak di bawah $10,4 \mathrm{mmol} / \mathrm{L}$ atau $187,2 \mathrm{mg} / \mathrm{dl}$ [4].

Tikus galur wistar (Rattus novergicus) diperoleh dari Unit Hewan Coba Laboratorium Farmakologi dan Terapi Fakultas Kedokteran Universi- 
tas Airlangga. Besar sampel yang dipakai dalam penelitian dihitung menggunakan rumus:

$$
(\mathrm{t}-1)(\mathrm{r}-1)>15
$$

Dimana $\mathrm{t}$ adalah banyaknya kelompok perlakuan dan $r$ adalah jumlah replikasi. Pada penelitian ini terdapat 4 kelompok hewan coba, yaitu satu kelompok sebagai kontrol (KD) dan tiga kelompok perlakuan (K1-K3), maka jumlah replikasi untuk setiap perlakuan dapat dihitung dengan rumus Federer [5]:

$$
\begin{gathered}
(\mathrm{t}-1)(\mathrm{r}-1)>15 \\
(4-1)(\mathrm{r}-1)>15 \\
r-1>5 \\
\mathrm{r}>6
\end{gathered}
$$

Replikasi dilakukan untuk menghindari kemungkinan hewan coba mati $(\mathrm{f})=25 \%$ selama penelitian maka besar replikasi dikalikan $1 / 1$ - $\mathrm{f}$, sehingga: $1 /(1-0,25)$ x $6=7,99=8$ (besar sampel dibulatkan). Jumlah sampel pada penelitian ini adalah 8 ekor per kelompok perlakuan sehingga besar sampel keseluruhan 32 ekor. Pengambilan sampel dilakukan dengan menggunakan teknik simple random sampling karena sampel diambil dari populasi yang dilakukan secara acak (random) dengan tidak mempertimbangkan strata atau tingkatan dalam populasi. Penggunaan hewan uji telah mendapatkan surat persetujuan dari komisi etik Fakultas Kedokteran Gigi, Univesitas Airlangga dengan nomor surat 005/ HRECC.FODM/1/2017 tertanggal 4 Januari 2017.

Kelompok kontrol diberikan aquades, sedangkan 3 kelompok perlakuan diberikan larutan fruktosa dengan konsentrasi berturut-turut 2, 5, dan $9 \mathrm{~g} / \mathrm{kgBB}$, semua kelompok diberikan perlakuan secara intragastrik selama 56 hari.

\subsection{Penyiapan larutan fruktosa}

Fruktosa yang digunakan merupakan senyawa $D$-fructose $>99 \%$. Larutan fruktosa dibuat setiap 1 minggu sekali untuk menjaga kestabilan larutan dan pemberian pada hewan didasarkan pada berat badan. Larutan fruktosa dibuat dengan konsentrasi 20\% yaitu dengan cara melarutkan $20 \mathrm{~g}$ D-fructose ke dalam $100 \mathrm{ml}$ aquades. Pemberian larutan fruktosa disesuaikan dengan berat badan masing-masing hewan coba dan diberikan secara intragastrik selama 56 hari. Larutan fruktosa diletakkan pada botol kaca yang bagian luarnya dilapisi oleh alumunium foil untuk mencegah proses fermentasi.

\subsection{Biokimia darah}

Sampel darah dianalisis sebelum perlakuan diberikan, saat perlakuan diberikan sampai hari ke-30 dan ketika perlakuan berakhir pada hari ke-56. Sampel darah yang dianalisis sebelum diberikan ditujukan untuk melihat kadar glukosa darah normal pada hewan coba dan untuk memastikan bahwa hewan coba yang digunakan pada eksperimen memenuhi kriteria inklusi. Pengukuran kadar glukosa darah ketika perlakuan berlangsung sampai hari ke-30 untuk mengevaluasi adanya peningkatan kadar glukosa darah setelah diberikan perlakuan. Pada tahap ini, pengukuran glukosa darah dilakukan melalui ekor dengan menggunakan glukometer, yang sebelumnya telah dipuasakan selama 4-5 jam. Pada hari ke-56 setelah diberikan perlakuan, hewan coba dipuasakan selama 4-5 jam kemudian dianestesi dengan menggunakan dietil eter, sampel darah dikumpulkan dengan segera untuk selanjutnya dianalisis menggunakan spektrofotometer UV.

\subsection{Analisis data}

Data dianalisis secara statistik dengan menggunakan one way ANOVA $(\alpha=0,05)$. Sebelum diuji dengan one way ANOVA, data terlebih dahulu diuji dengan Kolmogorov-Smirnov untuk mengetahui data terdistribusi normal atau tidak. Jika terdapat perbedaan yang bermakna, maka untuk mengetahui beda antar perlakuan digunakan uji LSD (Least Significant Difference) atau Uji Beda Nyata Terkecil. Semua analisis dilakukan dengan bantuan SPSS 20.0 for windows.

\section{Hasil dan diskusi}

Penelitian ini adalah penelitian True Experimental Laboratories dengan menggunakan hewan coba sebanyak 32 ekor tikus putih (Rattus nover- 
gicus) jantan strain Wistar pada awal penelitian, dengan rincian 6 ekor hewan coba dan dilebihkan 2 ekor untuk menghindari kemungkinan hewan coba mati selama penelitian, digunakan pada setiap kelompok penelitian yang meliputi KD, K1, K2, K3. Namun jumlah hewan coba yang dipakai untuk pengumpulan data sebanyak 24 ekor, yang diambil secara acak dengan jumlah 6 ekor hewan coba pada masing-masing kelompok penelitian.

Pada awal penelitian, yaitu 14 hari setelah aklimatisasi dilakukan penimbangan berat badan hewan coba (Tabel 1) untuk memastikan berat badan hewan coba yang digunakan pada penelitian memenuhi kriteria inklusi, yang selanjutnya disebut sebagai BB awal. Berat badan hewan coba ini yang selanjutnya akan dijadikan bahan pertimbangan penyesuaian dosis dan volume larutan fruktosa yang diberikan. BB tengah merupakan berat badan hewan coba yang diukur saat hari ke-30 setelah diberikan perlakuan induksi fruktosa. Tujuan penimbangan BB tengah adalah untuk mengevaluasi adanya peningkatan BB selama pemberian induksi fruktosa yang selanjutnya

Tabel 1. Data berat badan hewan coba* digunakan untuk menyesuaikan dosis fruktosa. Data BB tengah (Tabel 1) menunjukkan bahwa terdapat kenaikan BB yang signifikan sesuai dengan kenaikan dosis fruktosa yang diberikan. Pada akhir penelitian, sebelum hewan coba dikorbankan, BB ditimbang dan dinyatakan sebagai BB akhir untuk mengetahui BB hewan coba di akhir penelitian. Data BB akhir (Tabel 1) menunjukkan bahwa kenaikan BB tidak signifikan, bahkan terdapat beberapa hewan coba yang mengalami sedikit penurunan BB. Berat badan pada penelitian ini dapat digunakan sebagai salah satu parameter obesitas pada hewan coba yang berhubungan dengan perkembangan resistensi insulin akibat pemberian induksi fruktosa.

Glukosa darah puasa (GDP) hewan coba (Tabel 2) juga diukur pada awal penelitian untuk memastikan bahwa hewan coba yang digunakan pada penelitian dalam kondisi sehat dan tidak menderita hiperglikemia, sebagai pertimbangan hewan coba masuk ke dalam kriteria inklusi. Pada hari ke-30 GDP diukur kembali dan dinyatakan sebagai GDP tengah untuk mengevaluasi adanya

\begin{tabular}{lllll}
\hline Kelompok & n & BB awal $(g)$ & BB tengah $(g)$ & BB akhir $(g)$ \\
\hline KD & 6 & $186,00 \pm 15,63$ & $278,50 \pm 12,52$ & $299,50 \pm 31,51$ \\
K1 & 6 & $179,50 \pm 5,24$ & $264,33 \pm 14,18$ & $284,00 \pm 18,96$ \\
K2 & 6 & $182,67 \pm 10,31$ & $271,17 \pm 49,18$ & $269,33 \pm 51,59$ \\
K3 & 6 & $191,17 \pm 9,81$ & $295,50 \pm 26,74$ & $304,50 \pm 23,13$ \\
\hline
\end{tabular}

*data BB menunjukkan rerata \pm SD

Tabel 2. Data kadar glukosa darah puasa*

\begin{tabular}{lllll}
\hline Kelompok & n & GDP awal $(\mathbf{m g} / \mathbf{d l})$ & GDP tengah $(\mathbf{m g} / \mathbf{d l})$ & GDP akhir $(\mathbf{m g} / \mathbf{d l})$ \\
\hline KD & 6 & $106,17 \pm 11,48$ & $103,83 \pm 6,15$ & $99,67 \pm 6,38$ \\
K1 & 6 & $104,33 \pm 6,19$ & $168,17 \pm 13,53$ & $176,50 \pm 14,73$ \\
K2 & 6 & $99,67 \pm 6,38$ & $184,67 \pm 12,86$ & $152,83 \pm 28,49$ \\
K3 & 6 & $102,17 \pm 12,55$ & $192,67 \pm 20,39$ & $221,00 \pm 40,53$ \\
\hline
\end{tabular}

*data GDP menunjukkan rerata \pm SD

kenaikan glukosa darah selama pemberian induksi fruktosa. Pada pengamatan ini, GDP masih belum menunjukkan kenaikan yang signifikan sehingga belum dapat dikatakan sebagai hiperglikemia. Selanjutnya pada akhir penelitian, yaitu pada hari ke-56 setelah pemberian induksi fruktosa, GDP diukur kembali dan menunjukkan adanya kenaikan yang signifikan dibandingkan GDP pada awal penelitian, sebanding dengan kenaikan dosis fruktosa yang diberikan. Namun pada 
penelitian menunjukkan bahwa semakin besar dosis fruktosa yang diberikan menyebabkan semakin meningkatnya resiko diare pada hewan coba sehingga resiko kematian hewan coba juga semakin meningkat.

Dari hasil analisis data BB dan GDP di atas menunjukkan adanya kesesuaian dengan penelitian sebelumnya yang menyatakan bahwa pemberian induksi diet tinggi fruktosa secara ad libitum memicu pembentukan jaringan adiposa di abdominal dan kenaikan berat badan [6]. Pada penelitian ini, hewan coba dibuat model DM tipe II dengan diberikan diet tinggi fruktosa melalui rute intragastrik selama 56 hari dengan konsentrasi berturut-turut 2, 5, dan $9 \mathrm{~g} / \mathrm{kgBB}$. Data hasil penelitian menunjukkan bahwa kelompok hewan coba yang diberikan perlakuan diet tinggi fruktosa mengalami hiperglikemia pada hari ke56. Fruktosa digunakan sebagai induksi DM tipe 2 pada penelitian ini karena dapat menginduksi terjadinya resistensi insulin $[7,8,9]$.

Berdasarkan hasil uji komparasi pada penelitian ini dapat diketahui bahwa terdapat perbedaan bermakna antar kelompok $(p<0,05)$ pada variabel dosis fruktosa dan kadar GDP akhir. Hal ini membuktikan bahwa pemberian fruktosa secara intragastrik jangka panjang dapat meningkatkan kadar glukosa darah. Fruktosa dipilih sebagai induksi DM tipe 2 karena memiliki ciri metabolik yang unik yaitu dapat masuk ke dalam sel dengan tidak bergantung insulin, tetapi dimetabolisme oleh organ splanik. Fruktosa dapat masuk ke dalam sel melalui karier membran GLUT5 di enterosit sehingga tidak bergantung pada natrium dan tidak memerlukan energi. Selanjutnya sebagian besar fruktosa akan diabsorbsi melalui usus menuju vena porta dan masuk ke dalam hepatosit melalui GLUT2. Di dalam hepatosit, fruktosa secara cepat akan diubah oleh enzim fruktokinase menjadi fruktosa-1 fosfat dan kemudian diubah menjadi triose fosfat oleh enzim aldolase B. Kedua enzim ini tidak dipengaruhi baik oleh insulin maupun status energi pada sel. Peningkatan konsentrasi triose fosfat di hepatosit akan memicu laju konsumsi ATP hepatik yang tinggi pada awal fosforilasi fruktosa, sehingga ketika intake fruktosa tinggi memicu deplesi ATP, pembentukan AMP dan degradasi adenosin menjadi asam urat. Akumulasi triose fosfat akan diubah menjadi laktat atau glukosa yang akan dilepas ke sirkulasi (glukoneogenesis). Selain itu penumpukan triose fosfat dapat menstimulasi sintesis glikogen dan asam lemak dari karbon pada fruktosa melalui jalur metabolik yang dikenal dengan istilah de novo lipogenesis [9]. Proses de novo lipogenesis akan memicu pembentukan jaringan adiposa di abdominal yang merupakan komponen penting dalam perkembangan dislip-

GDPAakhir

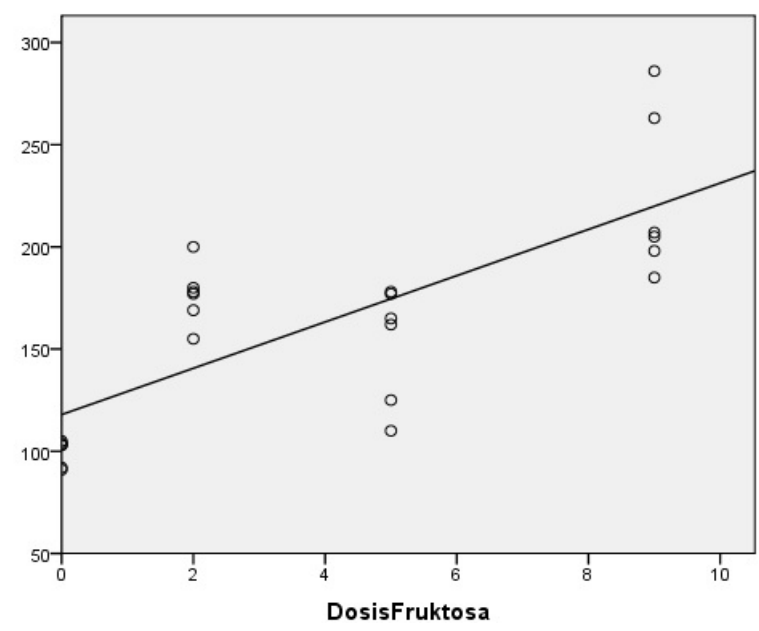

Gambar 1. Kurva regresi linier antara dosis fruktosa dengan kadar GDP akhir 
idemia, hiperglikemia, dan hipertensi. Hal ini ditunjukkan dengan meningkatnya BB hewan coba selama diberikan induksi diet tinggi fruktosa. Pembentukan asam lemak dari proses de novo lipogenesis yang berlebihan dapat menurunkan sensitivitas insulin sehingga menyebabkan penurunan ambilan glukosa oleh jaringan yang sensitif insulin. Keadaan ini memicu proses lipolisis sehingga asam lemak bebas dan gliserol yang dihasilkan akan lebih banyak. Asam lemak bebas dan gliserol masuk kedalam jaringan adiposa dalam bentuk TG. Siklus ini akan terus terulang sehingga akan semakin banyak TG yang terbentuk [6]. Sensitivitas insulin yang menurun akibat penumpukan TG ini yang memicu terjadinya resistensi insulin. Proses ini melibatkan 4 jalur utama yaitu mekanisme aksi produk lipid terhadap sel otot (muscle lipototoxicity), mekanisme aksi asam urat terhadap NO pada disfungsi endotel, mekanisme aksi ROS, dan mekanisme aksi inflamasi yang dapat mengaktivasi jalur NFKB. Konsumsi tinggi fruktosa akan mengakibatkan akumulasi senyawa pada jalur tersebut sehingga dapat menegaskan bahwa fruktosa memiliki peran yang besar dalam memicu terjadinya resistensi insulin [10]. Hal ini sesuai dengan penelitian yang menunjukkan bahwa pemberian diet tinggi fruktosa selama 56 hari berturut-turut dapat menginduksi terjadinya hiperglikemia. Semakin besar dosis fruktosa yang diberikan, menunjukkan kenaikan GDP yang semakin tinggi (Gambar 1), namun juga perlu diwaspadai peningkatan resiko diare dan kematian pada hewan coba.

\section{Kesimpulan}

Pemberian fruktosa secara intragastrik jangka panjang dapat menginduksi terjadinya hiperglikemia pada tikus model DM tipe 2. Penelitian ini dapat memberikan alternatif solusi dalam pengembangan model hewan coba DM tipe 2 yang lebih akurat karena dosis fruktosa yang diberikan lebih terukur dan seragam karena diberikan secara intragastrik dengan dosis ter- tentu. Selain itu metode ini juga lebih terjangkau karena dapat meminimalisasi kematian hewan coba yang sering ditimbulkan oleh senyawa kimia penginduksi DM tipe 2 lain yang dapat merusak pankreas. Penggunaan fruktosa jangka panjang juga sesuai dengan pendekatan pola konsumsi gula pada manusia yang dapat menginduksi terjadinya hiperglikemia.

\section{Daftar pustaka}

1. Depkes RI. Riset Kesehatan Dasar. Jakarta: Badan Penelitian dan pengembangan Kesehatan Kementrian Kesehatan RI. 2013

2. Khitan Z, Kim DH. Fructose: a key factor in the development of metabolic syndrome and hypertension. Journal of nutrition and metabolism. 2013; May 25.

3. Dupas J, Goanvec C, Feray A, Guernec A, Alain C, Guerrero F, Mansourati J. Progressive Induction of Type 2 Diabetes: Effects of a Reality-Like Fructose Enriched Diet in Young Wistar Rats. PLoS One. 2016;11(1):e0146821.

4. Rimbun. Ekspresi Reseptor Insulin di Jaringan Otot dan Hepar Tikus Putih Jantan yang Diberi Diet Tinggi Lemak dan Suntikan Streptozotocin Dosis Rendah sebagai Model Hewan Coba Diabetes Mellitus Tipe 2. Tesis. Program Magister Universitas Airlangga Surabaya; 2014.

5. Federer WT. Statistics and society: data collection and interpretation. 2nd edition. New York: Marcel Dekker; 1991.

6. Stanhope KL, Havel PJ. Fructose consumption: considerations for future research on its effects on adipose distribution, lipid metabolism, and insulin sensitivity in humans. The Journal of nutrition. 2009;139(6):1236S-41S.

7. Livesey G. Fructose ingestion: dose-dependent responses in health research. The Journal of nutrition. 2009;139(6):1246S-52S.

8. Mamikutty N, Thent ZC, Sapri SR, Sahruddin NN, Mohd Yusof MR, Haji Suhaimi F. The 
establishment of metabolic syndrome model by induction of fructose drinking water in male Wistar rats. BioMed research international. 2014.

9. Tappy L. Q\&A:'toxic'effects of sugar: should we be afraid of fructose?. BMC biology. 2012;10(1):42.

10. Chen L, Chen R, Wang H, Liang F. Mechanisms linking inflammation to insulin resistance. International journal of endocrinology. 2015. 